\title{
НАГРАЖДЕНИЯ «ЦАРЕДВОРЦЕВ» ТРАДИЦИОННЫМИ МОСКОВСКИМИ ЧИНАМИ В ЭПОХУ ПЕТРА I
}

\author{
АНДРЕЙ В. ЗАХАРОВ \\ Национальный исследовательский университет «Высшая школа экономики» \\ Научно-учебная лаборатория междисциплинарных эмпирических исследований \\ Сектор исторических исследований \\ ул. Студенческая, 38, 614070, г. Пермь, Россия \\ e-mail: ELURAL@yandex.ru1 \\ (получено 10.08.2017; принято 27.09.2017)
}

\section{Abstract \\ Traditional Muscovite ranks for the «courtiers» in the Petrine epoch}

The article presents the research results on the last ennoblements to Duma and Muskovite ranks. Based on archival sources, the author reconstructs the reasons for ennoblement in the Muscovite ranks for the period from 1690 to 1725 in the context of the political events of the Petrine era in Russia. The author focuses on biographies of prestigious ranks holders as well as the last innovations into the traditional rank system for the Russian service elite. Before the publication of Tables of ranks, the institution of Moscow rank system was an important way of communication between the supreme power and subjects. The old ranks retained the function of award distinctions for service and had a respected position among courtiers, nobles and prominent dignitaries.

1 Статья подготовлена в ходе проведения исследования (№ 17-01-0100) в рамках программы «Научный фонд Национального исследовательского университета «Высшая школа экономики (НИУ ВШЭ)» в 2017-2018 гг. и в рамках государственной поддержки ведущих университетов Российской Федерации «5-100». 


\section{Key words}

Peter the Great, administrative reforms, Ceremonial ranks, Muscovite ranks, Russian elite, boyars, Boyar Duma, Sovereign's court, All-Drunken Synod of Fools and Jesters.

\section{Резюме}

В статье на основе архивных источников анализируется практика последних пожалований в думные и московские чины в России. В контексте политических событий Петровской эпохи реконструируются мотивы пожалований в старомосковские чины с 1690-х годов до 1725 года. Уточняются биографии обладателей престижных званий и последние новации в рефоре традиционных чинов для представителей российской служилой элиты. До публикации Табели о ранzax институт московского чинопроизводства был важным средством коммуникации верховной власти и подданных, сохранял функцию наградных отличий за службу и имел авторитетные позиции в среде придворных, знати и видных сановников.

\section{Ключевые слова}

Петр I, административные преобразования, гражданские чины, московские чины, служилая элита, бояре, Боярская дума, «всепьянейший собор».

Едва ли не все военные, социокультурные и административные преобразования царя Петра I современники и потомки сопоставляли с новизной и сломом традиций. Более того, образ наиболее ярких петровских реформы сам трансформировался в метафоры обновления. С насаждением неподатным слоям подданных венгерского костюма, парика, бритьем бород, низвергались старомосковские институции, уступая место новым изобретениям или небывалым названиям прежних практик. Современные исследования перемен в русском костюме, введения запретов на ношение бороды², смена названий отдельных учреждений на новые убедительно показывают, что нововведения по меркам десятилетий вводились с перерывами, постепенно, имели прецеденты до XVIII столетия, многократно повторялись, а первоначально принятые образцы новин могли видоизменяться.

Названию и системе чинов, доживших из глубин Московского царства, Петр I, как известно, противопоставил в конце своего царствования чины Табели

2 А.А. Абрамов. Портрет Петра I времени Великого посольства 1697 г. [В:] Труды Государственного Эрмитажа. Т. 70: Петровское время в лииах: К 400-летию Дома Романовых (1613-2013). Санкт-Петербург: Издательство Государственного Эрмитажа, 2013, с. 5-9; L. Hughes. „A Beard is an Unnecessary Burden”: Peter I's Laws on Shaving and their Roots in Early Russia. [B:] Russian Society and Culture and the Long Eighteenth Century: Essays in Honour of Anthony G. Cross. Ed. R. Bartlett, L. Hughes. Münster: Lit, 2004, c. 21-34. 
о рангах. Казалось бы, запрет старых званий светских служащих мог быть самой простой и эффективной мерой, но такого легкого решения не произошло. Даже после смерти царя думные, дворцовые и московские чины продолжали употребляться в государственном делопроизводстве и в частной переписке. На протяжении XVIII столетия наблюдается своеобразный феномен наследования старых именований. Потомок служилого человека из думных или московских чинов, дороживший честью рода или по иным мотивам, мог называть себя или внуком боярина или сыном стольника.

Насколько быстро, планомерно и безболезненно происходил отказ или смена перечисленных думных и московских чинов на новые, каковы мотивы замен, имелись ли рецидивы старомосковской практики в первой четверти XVIII столетия? Ответы на эти вопросы важны для понимания каналов коммуникации монарха и русской служилой элиты, для выяснения судеб московских служебных отличий и чиновных институций, появившихся и ставших традиционными в первое столетие Московского государства. Рудиментам традиции пожалования в чины думных людей после нескольких замечаний М.М. Богословского историки долгое время не уделяли должного внимания, а материал о «царедворцах», будучи распылен и фрагментарен, и вовсе не входил в орбиту внимания³

Практика именования обладателей высших чинов в доимперский период включала обширный ряд чиновных названий, аналогичных формулам «Соборного уложения» 1649 г.: «или за бояры, или за околничими и за думными и за комнатными людьми, и за стольники и за стряпчими и за дворяны московскими, и за дьяки, и за жильцы, и за городовыми дворяны и детьми боярскими, и за иноземцы, и из всякими вотчинники и помещики». Современному человеку тонкости отличий между разрядами «вотчинников и помещиков» малопонятны, а в исследовательской парадигме обобщений и поиска закономерностей, сословных начал, аналогов современного общества редко необходимы. С точек зрения социального и институционального подходов в историографии Петровской эпохи появлялись понятия «феодальная аристократия», «государев двор», или наиболее распространенные на сегодняшний день: «служилая элита», «бюрократия», «генералитет». Изучение повседневной истории такие термины если не отвергает, то заставляет с оговорками прибегать к обобщениям и терминологическим упрощениям. Дореволюционный термин «служилый класс», объясненный Н.П. Лихачевым и В.О. Ключевским, прижился в историографии. Этот конструкт во многом перекликается с современным научным понятием «служилая элита», под которой необходимо понимать представителей государственного и дворцового аппарата, рекрутированных на государеву службу любого вида и статуса по спискам думных, высших дворцовых и московских чинов, имевших возможность получения наивысших поместных окладов и денежных

3 М.М. Богословский. Петр I. Материалы для биографии. Т. 4. Москва: Госполитиздат, 1948, с. 243-258; М.П. Лукичев. Боярские книги XVII века: труды по истории и источниковедению. Москва: Древлехранилище, 2004; А.Н. Медушевский. Утверждение абсолютизма в России: сравнительное историческое исследование. Москва: Текст, 1994; M.T. Poe. The Russian Elite in the Seventeenth Century. Vol. 1-2. Helsinki: Academia Scientiarum Fennica, 2004. 
«дач» по сравнению с провинциальными (городовыми) служилыми людьми. Современники Московского государства также искали обобщения в контексте однотипности службы, поэтому в старорусском лексиконе закрепились термины: «думные», «московские чины», «комнатные» (то есть высшие дворцовые) и «царедворцы» ${ }^{4}$. Параллельно сосуществовало несколько систем чинов, которые мы видим с рациональной точки зрения современных критериев. В «московском списке» или «московских чинах» ${ }^{5}$ располагались снизу вверх: жильцы, дьяки, московские дворяне, стряпчие, стольники, всего около 11 тыс. человек к началу XVIII в. Обладатели этих чинов, за исключением дьяков, именовались «царедворцами». Выше стольников в иерархии чинов находились комнатные стольники, именовавшиеся в XVII в. спальниками, как служившие при комнате государя, «спавшие во Дворце». Статус спальников подчеркивался особо как дворцовых чинов ${ }^{6}$.

Верх служебной пирамиды венчал список думных чинов, называемых «палатными людьми», вновь следуя по перечням снизу вверх: думные дьяки, думные дворяне, окольничие, бояре. Особый служебный статус думных и высших дворцовых чинов подчеркивался их близким расположением в списках чиновного учета, хотя люди дворцовых степеней в Думу приглашались редко.

В высших чинах начинали служебную карьеру многие видные сподвижники Петра I. Думными чинами в боярских списках значились трое из восьми новоиспеченных губернаторов в 1708 г.: бояре Т.Н. Стрешнев, П.С. Салтыков и окольничий П.М. Апраксин; трое были комнатными стольниками: кн. П.А. и Д.М. Голицыны, Ф.М. Апраксин и печально известный сибирский губернатор, закончивший жизнь на висилице стольник кн. М.П. Гагарин,. Из восьми первых губернаторов московских чинов не имел только светлейший князь А.Д. Меншиков. В последнем составе 1725 г. из 10 губернаторов 6 человек происходили из комнатных стольников и по одному из бояр, стольников, жильцов ${ }^{7}$ и вновь «безчиновный» Меншиков. Несмотря на губернаторские назначения П.М. Апраксин и П.С. Салтыков именовались «ближними боярами» до своей смерти. Некоторое время после получения нового звания канцлера и впервые российского титула графа Г.И. Головкин одновременно именовался по-старому

\footnotetext{
4 А.В. Захаров. «Государев двор» и иаредвориы Петра I: проблемы терминологии и реконструкиии службы. [В:] Правящие элиты и дворянство России во время и после Петровских реборм (1682-1750). Ред. Н.Н. Петрухинцев, Л. Эррен, А.В. Доронин. Москва: Российская политическая энциклопедия, 2012, с. 10-44.

5 Оба термина являются аутентичными для XVII - начала XVIII в.

6 Выше спальников располагались высшие дворцовые чины по одному за каждым царем: стряпчий с ключом, постельничий, кравчий. После смерти Ивана V его дворцовые механически вошли в состав дворцовых Петра I.

7 В последнем составе губернаторов из бояр происходил кн. И.Ю. Трубецкой, комнатными стольниками были Ф.М. Апраксин, кн. М.В. Долгоруков, кн. Н.И. Репнин, Ю.А. Ржевский, кн. И.Ф. Ромодановский, А.Ф. Салтыков, стольник А.П.Волынский, жилец П.В. Измайлов.

8 См.: О.И. Хоруженко. Дворянские дипломы XVIII века в России. Москва: Наука, 1999, с. 25, $29-30$.
} 
постельничим. Задумав по наблюдениям иностранцев ${ }^{9}$ реформу чинов за десятилетие до Табели о рангах, Петр I не допустил одномоментного уничтожения учета «царедворцев». Из 16 президентов коллегий петровского времени 5 были из думного списка, 5 из комнатных стольников, 4 из московских чинов, «безчиновными» - только Я.В. Брюс и А.Д. Меншиков. Все губернаторы и президенты, лично знакомые царю с юности, как ближние люди, думцы и комнатные чины имели большие шансы зарекомендовать себя на службе.

Последними старомосковскими пожалованиями справедливо считать все случаи возведения в думные, высшие дворцовые и московские чины, зафиксированные приказной и сенатской документацией, после завершения ежегодных регулярных пополнений, то есть период 1695-1725 гг. Подробные записи о чинопроизводстве вносились Разрядным приказом в «записные книги всяких дел» до 1710 г., но позднейшие сохранившиеся книги 1693/94 г. и 1696/97 г. имеют значительные утраты текста, а за XVIII в. известны лишь копийные выписки. Записные книги факультативно сообщают основания пожалования, имена дьяков «сказавших» государев указ, форму этого сообщения и прежний чин награжденного. Лакуны утраченных книг отчасти восполняют другие разрядные документы $^{10}$, в том числе ежегодные боярские списки, которые за 1714-1719 гг. также утрачены. Это осложняет достоверно оценить наличие награждений последнего пятилетия.

В конце XVII в. ежегодные массовые пополнения старомосковских чинов в количественном отношении восполняли физически выбывавших из боярского списка. Количество думных чинов в пределах 160-170 человек ${ }^{11}$ значительно не изменялось до начала 1690-х гг. Государственный переворот августа 1689 г. немедленно вызвал волну награждений. Связанные родством и свойством 28 победивших сторонников Петра I или имевших клиентские отношения с Нарышкиными ${ }^{12}$, пополнили думный список. Напротив, думные почести стали недоступны сошедшим с политической сцены ближайшим родственникам вдовствующих цариц Марфы Матвеевны урожденной Апраксиной и царицы Прасковьи Федоровны урожденной Салтыковой. Чтобы не допустить нежелательный разлад с семьей «старшего царя» Ивана Алексеевича были пожалованы его спальники: В.Ф. Салтыков стал кравчим (1690), П.С. Салтыков - боярином (1691). Нарышкины были вынуждены терпеть среди думцев двух Милославских: Лариона Семеновича и Матвея Богдановича ${ }^{13}$. Вскоре после кончины царя

9 Г. Грунд. Доклад о России в 1705-1710 гг. Пер. Ю.Н. Беспятых. Санкт-Петербург: Институт российской истории, 1992, с. 138.

10 Двориовые разряды. Т. 3-4. Санкт-Петербург: Типография II Отделения Собственной Его Императорского Величества Канцелярии, 1852-1855 (далее - ДР).

11 За 1667-1678 гг. число людей с думным чином (без высших дворцовых чинов, но с печатником) увеличилось с 67 до 167 человек. См.: Российский государственный архив древних актов Ф. 210. Оп. 2 (Боярские списки). Д. 1. Л. 1-5 об.; Д. 15. Л. 1-15 (далее - РГАДА).

12 Нарышкины были возведены в течение трех лет после переворота 1689 г. в думные чины шесть раз и дважды их свойственники Лопухины. В.Ф. Нарышкин получил за весну и лето 1691 г. окольничество и боярство.

13 М.Б. Милославский оказался в окольничих в начале правления царя Федора в 1676 г., 
Ивана, Ларион Семенович заболел и скончался в 1698 г. Боярина Матвея Семеновича отправили в феврале 1697 г. доживать свой век «в деревню до указу» еще до путешествия Петра I в Европу. Позволения вернуться в столицу опальный Милославский так и не дождался, скончавшись в 1705 г.

Стремительное пополнение думного списка продолжались до 1694 г. $^{14}$ Приостановка в объявлении «чести боярской» объяснима достижением численного перевеса в думном списке победившего «клана» Нарышкиных и сменой механизма генерации пожалований. В 1695-1701 гг. отмечены редкими, не более чем двукратными пожалованиями в год. Таким образом, именно 1694 г. можно считать закатом регулярных думных пожалований, но не прекращением этой практики в целом.

Личная воля царя отчетливо видна в награждении думным дворянством посольского дьяка А.А. Виниуса 24 марта 1695 г. Нет сомнений, что Виниус заслужил высокую честь за успехи в приказном деле и за обучение царя голландскому языку ${ }^{15}$. Царь мог лично оценить даровитого и деятельного А.А. Виниуса во время первой архангельской поездки 1693 г. Сын обрусевшего голландца был едва ли не самым «бесчиновными» среди многочисленной царской свиты ${ }^{16}$. Его опыт был необходим царю как в походах, так и в столице. В новом качестве Виниус заседал в Думе в 1698-1701 гг. ${ }^{17}$ и возглавил Сибирский приказ. Особенно важно, что возвышение Виниуса было одним из первых самостоятельных решений Петра I на административном поприще.

Следующими думных почестей удостоились руководители Азовско-Днепровских компаний 1695-1697 гг. Командующего во втором Азовском походе корпусом московского дворянства кн. П. Г. Львова «великий государь (далее в. г., титул, имя.) пожаловал из стольников в окольничие и указал ему быть на своей в. г. службе в новозавоеванном городе Азове воеводою и сей свой в. г. указ в Розряде записать в книгу. Таков в. г. указ за пометою думнаго дьяка Никиты Зотова» ${ }^{18}$. Награждение кн. Львова 15 августа 1696 г. в день успения Богородицы должно было отметить и азовскую службу, и компенсировать смену вологодского воеводства на азовское. Окольничества удостоились думные дворяне:

в честь венчания царей Ивана и Петра был возведен 25 июня 1682 г. в бояре, а Л.С. Милославский в окольничие, став боярином на исходе правления Софьи 31 марта 1689 г.

14 С сентября по декабрь 1689 г. состоялось 4 пожалования в думные чины, в 1690 г. - 23, в 1691 г. - 21, в 1692 - 9, в 1693 - 7, в 1694 г. пожалований не было. См.: РГАДА. Ф. 210. Оп. 2. Д. 30-36.

15 Историки приписывают свидетельство успеха Петра I в освоении языка в надписи, вырезанной на деревянном кресте «Dat kruys maken kaptein Piter van a Chr. 1694», водруженным в память о спасении царя в морскую бурю на Беломорье в мае 1694 г. См.: Письма и бумаги имп. Петра Великого. Т. 1: 1688-1701. Санкт-Петербург: Гос. тип., 1887, с. 21, 495 (далее - ПБ). 16 Полное собрание русских летописей. Т. 33: Холмогорский и Двинской летописиы. Ленинград: Наука, 1977, с. 194.

17 А.В. Захаров. Государев двор Петра I: публикация и исследование источников разрядного делопроизводства. Челябинск: Челябинский государственный университет, 2009, с. 101-103. 18 ДР. Т. 4. Стб. 970. 
начальник «у провиантских дел» С.И. Языков (25 марта 1696 г. $)^{19}$ и воевода В.Б. Бухвостов, успешно оборонявший от крымчаков завоеванную крепость Тавань в 1697 г. $^{20}$ На третий день после приезда из Великого посольства царь удостоил Бухвостова заслуженной награды за выдержанную осаду на Таванском острове в низовьях Днепра. Спешка царя в объявлении чина подчеркивает важность самого действа. Источники не сообщают о присутствии царя на церемонии, но очевидно, что без его личного решения она не могла состояться: «206 году (1698 г.) августа в 28 день в. г. (имя, титул) пожаловал из думных дворян в околничие Василья Борисовича Бухвостова. В.г. жалованье честь сказывал думной дьяк Автамон Иванов сын Иванов» ${ }^{21}$. Вполне удачно сложилась дальнейшая служба азовских героев, спустя год, они заседали в кремлевских думных палатах ${ }^{22}$. Языков возглавил Провиантский приказ в новоизобретенной должности генерал-провианта с 1700 г., а Бухвостова отправили в 1701 г. в Псков укреплять крепость и ведать ратными людьми ${ }^{23}$. В годы Азовских походов царь еще не был готов жаловать ордена и новые титулы, а русская знать была не в состоянии принять и понять иные формы отличий. Денежные придачи и поместные оклады были несравнимы с получением высокого «палатного» статуса.

По сообщениям Г.К. Котошихина в XVII в. для отпрысков знатных боярско-княжескиих родов был обычным, когда «царь жаловал многих в бояре не по разуму их, но по великой породе» ${ }^{24}$. При Петре I это правило стремительно угасало. Именно за заслуги были отмечены родовитые участники АзовскоДнепровских акций, один из которых вошел в круг доверенных и влиятельных сотрудников царя. 20 июля 1697 г. «в. г. пожаловал из стольников комнатных князя Якова Федоровича Долгорукого честью в бояря. И о том сесь свой в. г. указ в Розряде записать в книгу, а к нему послать свою в. г. грамоту. В. г. указ о том за пометою думного дьяка Микиты Зотова в столпу у боярского списка» ${ }^{25}$. В конце мае 1697 г. Долгоруков двинулся сухим путем на соединение с силами гетмана И. Мазепы для защиты малороссийских городов и днепровских таванских крепостей от «татар». Боярство князь получил до успешного завершения задуманной военной акции, и, может быть слишком поспешно, заслужив вскоре и взыскания царя. Тем не менее, основным мотивом быстрого решения Петра I в пользу награждении кн. Долгорукова были известия о его белгородской

19 Там же. Стб. 1046.

20 ДР. Т. 4. Стб. 1046. И.А. Желябужский. Записки. [В:] Россия при иаревне Софье и Петре I: записки русских людей. Сост., автор вступит. ст., коммент. и указ. А.П. Богданов. Москва: Современник, 1990, с. 258.

21 ДР. Т. 4. Стб. 1082.

22 А.В. Захаров. Государев двор Петра I..., с. 99-100, 161-162, 275-277.

23 ПБ. Т. 2. Санкт-Петербург, 1889, с. 448.

24 Г.К. Котошихин. О России в изарствование Алексея Михайловича. 3-е изд. Санкт-Петербург, 1884, c. 27.

25 РГАДА. Ф. 210. Оп. 6. Д. 27 (Записная разрядная кника «всяких дел»). Л. 348 об. Указ «в столпу», то есть подклеенный в столбце с другими документами повытья боярского списка. 
службе $\mathrm{e}^{26}$. Воеводство в Белгороде кн. Я.Ф. Долгорукого - представителя одного из 15 «меньших» боярских родов (по терминологии Котошихина) было не менее востребовано для защиты пограничных рубежей и азовских завоеваний, чем служба кн. Львова, Языкова и Бухвостова. Как и прежде, сообщение боярства не привело мгновенно к возвращению в столицу. В документации участников боярских съездов 1698-1701 гг. имя Долгорукого не встречается. Как известно, думные чины лишь предоставляли право участия заседаний в Думе, не обязывая царя определять круг реальных советников.

Впервые с середины 1690-х годов высокой думной чести удостоились не родственнники и свойственники царицы Натальи Кирилловны, а деятельные сподвижники Петра I. Основания пожалований 1695-1698 гг. коренным образом отличались от предыдущих - обеспечивших сначала Софью, затем правительство Нарышкиных поддержкой лояльными сторонниками и соединенными узами родства. По достижении численного перевеса сторонников победившего «клана» Нарышкиных, Прозоровских и кн. Б.А. Голицына надобность в массовых пожалованиях исчезла, и список думных стал редеть вследствие естественной убыли. Дума наполнялась людьми с думным саном, бывшими в Москве; учитывалась их занятость в приказах «ради самых нужных дел» и здоровье ${ }^{27}$. Этот наличный состав думцев в 1697-1701 гг. не превышал 42 \% от перечня думных людей по боярскому списку ${ }^{28}$. Число и состав реальных советников царя все менее коррелировл с думным списком.

Последним в XVII в. думный чин получил окольничий И.А. Мусин-Пушкин, достигший в своем роду первым думных чинов и высшей боярской степени 9 сентября 1698 г. Постепенно он приобрел расположение царя как успешный воевода, был назначен первым начальником Монастырского приказа, стал графом и первым в списке сенаторов. Причину монарших милостей к Мусину-Пушкину необходимо искать вне его мифического образа как «единокровного брата» Петра I, тиражированного в литературе ${ }^{29}$. Разрядная записная книга передает текст грамоты с указом царя от 9 сентября 1698 г. с четко обозначенной причиной награды ${ }^{30}$. Вряд ли очевидное служебное рвение и успехи Мусина-Пушкина, отмеченного боярством, можно умалить недостоверным мотивом в официальной грамоте, объяснив еще более мифическим родством с царской семьей. После нескольких лет воеводства, после приезда в Москву в конце 1700 г. он приглашался на собрание думцев в Столовую палату Кремля 4 апреля 1701 г. $^{31}$

\footnotetext{
26 ПБ. Т. 1. С. $621,625$.

27 А.В. Захаров. Государев двор Петра I..., с. 31.

28 Там же, с. 395-398.

29 П.В. Седов. Закат Московского иарства: изарский двор кониа XVII века. Москва: Дмитрий Буланин, 2006, с. 113. Критика версии о рождении будущего графа в начале 1670-х годов от царя Алексея Михайловича см.: А.В. Захаров. Боярин и первый сенатор Иван Алексеевич Мусин-Пушкин на службе и в кругу семьи. [В:] Труды государственного Эрмитажа. Т. 78: Петровское время в лииах. Санкт-Петербург: Издательство Государственного Эрмитажа, 2015, c. 229-236.

30 ДР. Т. 4. Стб. 1085-1086.

31 РГАДА. Ф. 210. Оп. 9. Стб. 767. Л. 884.
} 
Сановник не скрывал гордости за свою службу, увенчанную боярским чином. В 1715 г. престарелый сенатор, как описывали Мусина-Пушкина современники, добиваясь титула графа, сочинил «Показание» о своих службах, четко объяснив свое боярство: «посылал на Аграхань на воровских козаков полковника Ивана Спешнева с ратными же людми... Потом посылан был на Еик на воровских же казаков, которые взяли Еик город, полковник Иван Меэр с ратными людми... Да при моей же бытности моим радением учинен немалой збор казне в. г. без всякие народные тягости, на что свидетелствуют купецкие люди розсияня и армяня ... И за сию мою службу пожалован я от в. г. в бояря» ${ }^{32}$. Саморефлексия пожалования полностью совпадает с оценкой подданного верховной властью.

Традиции продолжали поддерживаться в большей степени в атрибутике награждения. Объявление думного звания происходило, как правило, в великие праздники ${ }^{33}$ и царские дни. Во время «похода» на Воронеж, в свой день рождения 30 мая 1701 г. царь объявил думное дворянство И. И. Исленьеву, что было особой честью. Иван Исленьев происходил из дворянского рода. Его отец Иван Степанович, начавший службу стольником патриарха Филарета, был воеводой, назначался с дипломатическими миссиями, стал вторым судьей Судного Владимирского приказа, дослужился до стольника и московского дворянина, умер в 1668 г. Матерью И.И. Исленьева была княжна Мария Семеновна Друцкая, отец которой также был воеводой и вырос до дворян московских, был в стряпчих московского списка. Иван Иванович начал службу при царе Алексее Михайловиче, и впервые упомянут в челобитье на него А. Вельяминова 1659/60 г. о винной продаже. При дворе И. И. Исленьев впервые появился в чине стряпчего, возглавив в 1673 г. одну из 22 сотен жильцов, встречавших шведское посольство. Это позволяет предположить его рождение не позже начала $1640-\mathrm{x}$ годов. Будучи стольником на воеводстве в Муроме, на Алатаре в 1676-1677 гг. он мог воспользоваться таким же опытом своего отца. Новое воеводство Исленьев, возможно, получил в Шацке спустя 13 лет ${ }^{34}$. Совершенно неожиданно воевода «малых» городов сделал прыжок в 1685/86 г. до чина комнатного стольника Петра I, в который жаловались либо наиболее приближенные лица, либо их дети. На тот момент Исленьеву должно было исполниться около 45 лет, он был женат первым браком на дочери московского дворянина Домне Семеновне Чаплиной ${ }^{35}$. Свояченица Исленьева Акулина Семеновна была замужем за тро-

32 Д.О. Серов. Администрация Петра І. Москва: ОГИ, 2007, с. 243-244.

33 Думные пожалования состоялись: кн. П.Г. Львову в праздник Успения Пресвятой Богородицы (15 августа 1696 г.), С. И. Языкову в Благовещение Пресвятой Богородицы (25 марта 1697 г.), В. Б. Бухвостову - «в навечерии праздника Усекновения главы святого пророка предтечи и крестителя Иоанна» (28 августа 1698 г.).

34 Русская историческая библиотека, издаваемая Археографической комиссией. СанктПетербург: Печатня В.И. Головина, 1907. Т. 21. Стб. 318. ДР. Т. 3. СПб., 1852. Стб. 915-916, 1158, 1195; Т. 4. СПб., 1855, с. 107; Т.А. Лаптева. Провинциальное дворянство России в XVII в. Москва: Древлехранилище, 2010, с. 467.

35 В. и Г. Холмогоровы. Исторические материалы о иерквах и селах XVI-XVIII вв. Вып. 11: Верейская, Дмитровская и Троицких вотчин десятины (Московского уезда). Москва: Изд. Императ. о-ва Истории и Древностей Российских при Моск. ун-те, 1911, с. 203, 243. 
юродным дядей Петра I боярином Кондратием Фомичем Нарышкиным ${ }^{36}$. Вот почему безвестному Исленьеву удалось попасть в царские спальники. Вероятно, то же свойство с Нарышкиными в связи с успешной службой помогли пробиться к желанной ступени думного дворянина. В разрядной документации вновь были опущены подробности награждения, лишь отмечено, что «подлинной вел. г-ря указ закрепил думной дьяк Микита Моисеев сын Зотов» ${ }^{37}$. В 1702 г. Исленьев в числе «походных ближних людей» был в составе 4-тысячного царского двора, державшего путь к Архангельску и Соловецкому монастырю ${ }^{38}$. Вскоре после дальнего похода он скончался в 1703 г. $^{39}$.

Через месяц после награждения Исленьева в Петров день на царские именины думное дворянство дождался известный «князь-папа всешутейшего собора» Н.M. Зотов. Сначала была удовлетворена просьба думного дворянина и печатника Д.М. Башмакова об отставке с 29 июня 1701 г.: «по указу вел. г-ря по ево челобитью для старости печать у него принята и велено ево писать думным дворянином» ${ }^{40}$. На должность судьи Печатного приказа издавна назначались люди неподкупные, обличенные особым доверием царя, опытные приказные дельцы. Совпадение дат повышения Зотова и отставки Башмакова говорит о продуманной подготовке царского указа. Сметливость Зотова в прошении ${ }^{41}$ графского диплома в 1710 г. намекает на такую же бурную деятельность десятилетием ранее. Основание думного пожалования 1701 г. удалось извлечь из чернового отпуска и материалов, подготовленных для графского титула. Опубликованный подлинник диплома глухо касается мотивов пожалования ${ }^{42}$, в пространной «копии» бумаг они изложены несколько подробнее: «...в начале с салтаном Турским под Азовом будучи посольских дел и военного управления министром, неусыпное попечение имел, за что по взятии города восприял от нас гербовное знамя и по чину победы золотую монету, последи же в думныя дворяня и печетники пожаловали...» ${ }^{43}$. Черновой «отпуск патента» на графство полнее разворачивает историю чиновного успеха Зотова: «... от юности нашея... в чине дьяцем в крайную милость нашего в[еличества] восприяли и от оного обучались руского писания, а потом за верные его услуги и непрестанное

36 В.В. Руммель, В.В. Голубцов. Родословный сборник русских дворянских фамилий. Т. 2. Санкт-Петербург: Издание А. С. Суворина, 1887, с. 647.

37 РГАДА. Ф. 199. ЕД. хр. 130. Ч. 16. Д. 1. Л. 12.

38 Досифей. Летописеи, Соловецякий на четыре столетия, от основания Соловецкого монастьря до настоящего времени, то есть с 1429 по 1833 год. 3-е изд. Москва: В Унив. тип., 1833, c. 100; Ю.Н. Беспятых. Третье «пришествие» Петра I на Белое море. [В:] Архангельск в XVIII в. Сост. и отв. ред. Ю.Н. Беспятых. Санкт-Петербург: Русско-балтийский информ. центр «БЛИЦ», 1997, с. 31-32.

39 РГАДА. Ф. 210. Оп. 2. Д. 49. Л. 7.

40 Там же. Д. 45. Л. 8.

41 Древняя Российская вивлиофика. Изд. Н.И. Новиковым. Ч. 9. Москва: Типография компании типографической, 1789, с. 476.

42 ПБ. Т. 11. М.; Л., 1962, с. 243-244.

43 Древняя Российская ... Ч. 9, с. 479. 
при нас пребывание в думные дьяки пожаловали, потом ${ }^{44}$ же усмотря его великую к нам верность, усердие и разум до тайных наших советов... допустили, которым советы он нам в. г. во многих случаях в прошлои с салтаном Турским войне при атаках Азова пребывая всегда при нас многия верные услуги нам в. г. показал, за что мы его в наши думные дворяне и печатники пожаловали» ${ }^{45}$. Думное дворянство Зотова «запаздывает» на четыре года от окончания азовской службы, что свидетельствует о личном прошении думного отличия. Указ о повышении Зотова закрепил устроитель Карловицкого перемирия П. Б. Возницын ${ }^{46}$.

За несколько дней до думного возвышения Зотова Петр I утвердил новое чиновное изобретение: «Июня в 26 день (1701 г.) великий государь пожаловал ево (Возницына. - А. 3.), велел в боярских книгах и списках и во всяких письмах писать ево с вичем выше думных дьяков» ${ }^{47}$. Впервые вводилось официальное именование «советника», разумеется, пока еще «думного». Зная заранее грядущий переворот Табели о рангах, первые чиновные преобразования Петра I нашему современнику показались бы мелкими и паллиативными. В начале XVIII в. придуманное звание выглядело смелым шагом, но уже по проторенной дороге. Царевна Софья и кн. В. В. Голицыным от имени юных царей наградили полковника А. А. Шепелева новым чином думного генерала в 1682 г. ${ }^{48}$ Спустя почти 20 лет уже для выходца из дьячества учреждалось звание «думный советник», приближенное к высшему чину для неродовитых служилых людей - к думному дворянству. Вряд ли Прокофий Богданович Возницын претендовал на эту новину, навсегда исчезнувшую из истории служебных отличий с его смертью 4 февраля 1702 г. $^{49}$.

Новые звания удивительно быстро впитывались канцелярским лексиконом. Так, например, эхо пребывания боярина Б. П. Шереметева на Мальте в 1698 г. ежегодно повторялось в боярских списках с 1700 г. новым почетным званием «кавалера мальтийского», выделяя особую служилую почесть в сухом перечне имен. Сохранился неизвестный ранее указ царя от 28 января 1701 г. $^{50}$, закрепленный думным дьяком Г. Ф. Деревниным, о написании Б. П. Шерметева «ге-

44 Напротив этого слова на поле листа имеется вставка: «(первые два слова неразборчивы) садержание, каторое приписано для того, что неведомо в котором году то было и за то в какой он чин пожалован был».

45 РГАДА. Ф. 154. Оп. 2. Д. 68. Л. 2 об.

46 РГАДА. Ф. 199. ЕД. хр. 130. Ч. 16. Д. 1. Л. 15-15 об.

47 «Вичем» - то есть полным отчеством. РГАДА. Ф. 210. Оп. 2. Д. 45. Л. 10.

48 Шепелев в 1657/58-1675/76 был дворянином московским, в 1676/77 г. был пожалован чином генерал-майора, позже назначен генерал-поручиком, в 1682/83 г. стал первым и единственным (sic) думным генералом, его было велено писать выше думных дворян. Точная дата пожалования в думные генералы не была зафиксирована боярскими списками.13 октября 1687 (sic) г. он стал окольничим (РГАДА. Ф. 210. Оп. 2. Д. 27. Л. 9).

49 Возницын был впервые после переговоров приглашен в Думу 14 октября 1699 г., участвовал на «съездах» в феврале 1700 г. Дата и год его смерти в историографии прежде были неизвестны. См.: А.В. Захаров. Государев двор Петра І.., с. 106; РГАДА. Ф. 210. Оп. 2. Д. 46. Л. 7. 50 РГАДА. Ф. 199. Ед. хр. 130. Ч. 16. Д. 1. Л. 4. 
нералом и военным кавалером мальтииским свидетельствованным». В другом случае постельничий Г. И. Головкин стал называться в боярских списках с 1711 г. «государственным канцлером, тайным советником и ковалером, графом». Тогда же в перечне бояр кн. Я. Ф. Долгорукий был записан как сенатор и «тайной советник, генерал пленипотенциар крикс камисар». Прижились не все словесные эксперименты Петра I. Однажды у имени комнатного стольника кн. Н.И.Репнина было приписано: «генерал рыденбант Святаго апостола Андрея» ${ }^{51}$.

После награждений Возницына и Зотова список думных людей не пополнялся долгие восемь лет до Полтавской победы. Своеобразный «ренессанс» возведения в думные чины, как ни парадоксально, открыло письмо не обладавшего даже московскими чинами А. Д. Меншикова к главе Разрядного приказа Т.Н. Стрешневу. Подчиненный светлейшего князя по Ижорской канцелярии B.C. Ершов был пожалован думным дьячеством в 1709 г. и впервые в боярском списке: «октября в 15 день указ о том за рукою ${ }^{53}$ боярина Тихона Никитича Стрешнева» ${ }^{54}$. Позднее была сделана помета: «По писму от светлейшаго князя. Оборкамисар от ковалерии».

Следующее более заметное награждение также не могло состояться без царской воли. Петр I пожаловал 22 января 1710 г. казанского губернатора окольничего П. М. Апраксина в бояре ${ }^{55}$. Среди трех сенаторов, некогда состоявших в боярах, он единственным официально именовался «ближним боярином, графом» до смерти, что подчеркивало его уважение к чести боярской ${ }^{56}$. Приобретя опыт думного возвышения, новоявленный боярин Апраксин, испрашивал в 1715 г. у царя новый графский титул. Пожалования Ершова и Апраксина возродили впечатление доступности думных званий, и царь пресек возможную волну прошений необычным способом.

Счастливцами обладания заветных чинов оказались люди различного социального статуса: деятельные царедворцы и... шуты ${ }^{57}$. Одним из организаторов «всешутейшего и всепьянейшего собора» был кн. Юрий Федорович Шаховской, созывавший особыми повестками всех «соборян» и придворных двора на очередное действо. Известный в шутовской иерархии как «архидиакон Гедеон», он был объявлен боярином из комнатных стольников на Светлой неделе 12 апреля 1710 г. в компании с шутами Патрикеевым и Бутурлиным. Мотив Шаховского

51 См.: РГАДА. Ф. 210. Оп. 2. Д. 58. Л. 2, 5, 9. Прозвание Репнина как кавалера ордена необходимо считать казусом, поскольку факт орденского награждения не отмечались в списках московских чинов у прочих кавалеров: бояр, комнатных стольников и стольников.

52 Сведения Маршала По о В. Ершове как думном дьяке с 1690-х гг. ошибочны. Его имя вписали в боярскую книгу 1691/92 г. в 1711 г. в момент назначения «новичного» оклада (250 руб.). Книга спорадически пополнялась записями до 1716 г. Ср.: М.T. Poe. The Russian Elite in the Seventeenth Century...

53 В боярской книге 1691/92 г. в этом месте написано «за приписанием». РГАДА. Ф. 210. Оп. 1. Д. 11. Л. 47.

54 См.: РГАДА. Ф. 210. Оп. 2. Д. 56. Л. 8 об.

55 Там же. Д. 57. Л. 2 об. Ближним боярином до смерти также именовался и П.С. Салтыков.

56 Там же. Ф. 248. Д. 641. Л. 38.

57 РГАДА. Ф. 210. Оп. 2. Д. 56. Л. 2 об., 4 об.; Д. 58. Л. 2,6 об. 
очевиден. Его отец князь Федор Иванович достиг той же ступени в сентябре 1682 г. за верную службу в первом Троицком походе. Младший Шаховской назывался шутом современниками. В действах «соборян», как известно, были расписаны роли и «звания» крупных сановников, придворных, царя ${ }^{58}$. Петровский дипломат кн. Б.И. Куракин нелестно описывал все царское окружение и назвал Шаховского человеком «ума немалого и читателя книг, токмо самой злой сосуд и пьяной» ${ }^{5}$. Необходимо иметь ввиду, что четкую грань между шутом и служилым человеком провести не удастся. Сферы придворной и административной повседневности намеренно соединялись в контексте действий «соборян». Шутовские умения забавлять и разоблачать прегрешения придворных были поставлены царем в своеобразный род службы.

Одновременно с кн. Ю.Ф. Шаховским окольничим вмиг оказался «из ближних людей» Кузьма Хрисанфович Патрикеев, вероятно, он же «отец Козьма». Подобную свободу чиновной раздачи трудно представить по меркам XVII в., для соблюдения традиций это было симптоматично. Неродовитому человеку, не состоявшему в «московском списке», высокий чин окольничего первые Романовы могли позволить лишь родственникам царицы, какими новоявленные «думцы», естественно не являлись. Стольник Петр Васильевич Бутурлин по шутовскому прозвищу «Корчага» был произведен в думные дворяне, казалось бы, согласно всем канонам чинопроизводства. Его государева служба как и некоторых новоиспеченных «бояр» не исчерпывалась умением забавлять Двор. Светлейший князь Меншиков задействовал кн. Ю.Ф. Шаховского и П.В. Бутурлина заниматься обустройством Санкт-Петербурга по царскому указу от 16 августа 1711 г. Они «описали и меряли под загородные дворы землю и лес и во всяких местех». Совместно с окольничим кн. Ю.Ф. Щербатовым - по «совместительству» одним из «соборян» и двумя стольниками «бояря» составили книгу с описью 255 промеренных участков. Князь Шаховской приложил немало сил в защите Адмиралтейского острова новой столицы от пожаров в 1711-1713 гг. ${ }^{60}$ Неоднозначная роль шута в XVIII в. известна в историографии, менее известно, что уже в конце XVII в. состоялось пожалование шута Филата Шанского за службу, а не ради умаления московских чинов ${ }^{61}$.

58 Ю. Юль. Записки датского посланника в России. [В:] Лавры Полтавы. Москва: Фонд Сергея Дубова, 2001, с. 85; E.A. Zitser. The Transfigured Kingdom. Sacred Parody and Charismatic Authority at the Court of Peter the Great. Ithaca and London: Cornell University Press, 2004, c. $96-100$.

59 Г. Грунд. Доклад о России в 1705-1710 г2...., с. 129; Б.И. Куракин. Гистория о Петре І и ближних к нему людях. «Русская старина» 1890. Т. 68, № 10, с. 256.

60 Научно-исторический архив Санкт-Петербургского Института истории РАН. Ф. 83. Оп. 1. Д. 3762; Петербург в эпоху Петра I: документ в фондах и коллекииях НИА СПбИИ РАН. Каталог. Сост. Е.А. Андреева, Т.А. Базарова и др. Ч. 1. Санкт-Петербург: Санкт-Петербургский филиал архива РАН, 2003, с. 751.

61 С.Ф. Платонов. Из бытовой истории Петровской эпохи. Любимиы Петра Великого: Медведь, Битка и др. «Известия Академии наук СССР». Серия VI, № 9, с. 677-678. Ф.П. Шанский пожалован в стольники 12 января 1694. РГАДА. Ф. 210. Оп. 2. Д. 35. Л. 622. 
В январе 1711 г. аналогичной награды дождался и П.А. Ушаков, пиетет которого к чинам заметен даже по служебным спискам за десятилетие до думного сана. Прибыв на смотр московских чинов 11 августа 1700 г., он записался в число московских стряпчих «из серпуховских» служилых людей. В тот же год его имя неведомыми путями оказалось без каких-либо отметок о пожаловании в официальном списке стряпчих ${ }^{62}$. Разумеется, без его особых стараний этот казус не мог произойти. Позже Ушаков отправлялся по делам Казенного приказа, был выбран в «начальные люди», но прославился он при дворе на стезе шута. Однажды его «коптили на льду» реки Невы ${ }^{63}$, что похоже на очередной экстравагантный ритуал, изобретенный царем для развлечений. Ушаков, ревностно служивший государю, не мог примириться со своим прозванием «дурака». Он жаловался на обидные переклички своей фамилии с «Ушаков» на «Ишаков». Царь, шутливо принимая жалобы своего любимца, издал в надлежащем духе патент: «...господину думному дворянину, Прокопию Ушакову чернинькому мымричку дурачику-чку. Ведомо чиним всем, кому о том ведати надлежит, чтоб оного называли неупрямой фамилии веселинькой шутик или дурачик-чок; а хто ево назовет дураком, тем платить вышней саржи ${ }^{64}$ по золотому, другим рубль, третьему полтина, четвертому пол-полтины, самым низким гривна» ${ }^{65}$. В 1714 г. «шутик» умер и в тот же день «его величество смотрел анатомию» Ушакова. Церемонию его погребения в Александровом монастыре возглавил царь, прибывший с царицей, новгородским митрополитом и большой свитой на нескольких скампавеях ${ }^{66}$, что олицетворяет действительный статус усопшего как придворного. Могила Ушакова оказалась одной из первых на территории Александро-Невской лавры.

Пожалования одиозных личностей из «соборян» думными чинами по замыслу Петра I должны были отвратить после награждения В.С. Ершова и П.М. Апраксина погоню сановников и рядового «шляхетства» за думными чинами.

В ряд шутовских наград совершенно не вписывается объявление чина окольничего стольнику Юшкову и думного дворянства Тургеневу. Награждая А.А. Юшкова, Петр I собственноручно приписал в указе Сенату 4 ноября 1711 г.: «За многия и чрезвычайныя службы у служения и радения в върученных ему делех пожаловать сею честию» ${ }^{67}$. Шутом Петра I был его однофамилец Александр Юшков. Историк М.И. Семевский считал, что о награждении Алексея Александровича хлопотала царица Прасковья Федоровна, спасая его же сына Василия от отца. Младший Юшков был комнатным стольником и близким

\footnotetext{
62 Ушаков, судя по всему, позаботился о закреплении царского решения о производстве в чин: «В нынешнем 1711-м году генваря в 14-м числе в.г. пожаловал в думные дворяня ис стряпчих. Указ о том записан генваря 28-го 712-го года в Санкт Петербурхе». См.: РГАДА. Ф. 210. Оп. 2. Д. 58. Л. 6 об.; Д. 44. Л. 219; Д. 43. Л. 575.

63 Походный журнал 1712 г. Санкт-Петербург, 1913, с. 54.

64 От французского charge - чин. То есть высшим чинам.

65 Шуточный патент Петра Великого думному дворянину Прокопию Ушакову. Русский архив. 1865. Изд. 2-е. Москва 1866. Стб. 61-62.

66 Походный журнал 1714 г. Санкт-Петербург, 1913, с. 9, 102.

67 ПБ. М., 1964. Т. 11. вып. 2. С. 236. Ср.: РГАДА. Ф. 210. Оп. 2. Д. 58. Л. 4 об.
} 
человеком царицы и якобы был принужден отцом возвратить когда-то подаренные деревни; с помощью царицы старика «задобрили чином окольничего» ${ }^{68}$. Старший А.А. Юшков долго служил ${ }^{69}$, но сторонился «всепьянейших компаний соборян», за что кн. Ю. Ф. Шаховской грозил ему в 1709 г. отпиской всех имений на государя ${ }^{70}$. К моменту получения окольничества Юшкову было 64 года. И вполне понятно, что желание дослужиться до думных чинов им двигало с тех пор, как сын Василий превзошел отца по чинам, став спальником царя Ивана в 13 лет, а потом кравчим царевны Прасковьи. За плечами старшего Юшкова были три похода в XVII в., также три он пропустил, заплатив «вместо походов» деньги. В 1702-1703 гг. он находился у переписки монастырей, а в самые тяжелые годы войны избежал походной службы, сетуя «на головную и животную болезни». В 1705 г. его отправили воеводой в Белев на несколько лет. Несмотря на солидный возраст, он все-таки оказался «в армее» ${ }^{71}$ в 1711 г. у исполнения «чрезвычайных дел». Весомым аргументом окольничества как награды за военную службу является назначение ему оклада в 350 рублей в декабре 1712 г. $^{72}$ Служилых людей, достойных как Юшков думного награждения, было немало, но не каждый пользовался покровительством царицы.

Неоднозначным для объяснения оказывается награждение думным дворянством Семена Яковлевича Тургенева 28 января 1712 г. «из стольников». В источниках известен «веселящий» (шут) Семен Тургенев, личность которого до сих пор достоверно не идентифицирована. В отличие от других шутов, С. Тургенев в источниках не известен с упоминанием думного чина и с упоминанием отчества. Среди «царедворцев» в задаче идентификации необходимо исключить двоих: тезку Семена Павловича и тезку его отца Якова Гавриловича Тургенева, который не имел сыновей и был далек от царского двора ${ }^{73}$. Вероятнее всего, очередное награждение думным чином касалось бывшего в 1690-е годы новосильского воеводы, далекого от ролей шутов и «соборян». В пользу этого свидетельствует «исчезновение» из списков служилых людей 1714-1722 гг. пожилого С.Я. Тургенева, в то время как шут С. Тургенев был еще жив в 1725 г.

Вновь четыре шутовских награждения были объявлены в день Пасхи 20 апреля 1712 г. Боярином из стольников стал П.И. Бутурлин, принявший звание «князь-папы» после смерти Н.М. Зотова. По царскому указу он созывал славельщиков, «соборян», как в свое время кн. Шаховской. Любопытно, что совместно с ним в устроении церемоний «всешутейшего собора» был задействован даже правительствующий Сенат. Исполняя желание царя, сенаторы

68 Документальных отсылок на это известие у Семевского нет. См.: М.И. Семевский. Царица Прасковья. Москва: Художественная литература. Ленинградское отделение, 1989, с. 23-24.

69 В сказке, поданной в Разряд А. А. Юшков объявил, что служит с 1670/71 г. РГАДА. Ф. 210. Оп. 2. Д. 50. Л. 49.

70 Там же. Оп. 17. Д. 8. Л. 87.

71 РГАДА. Ф. 210. Оп. 2. Д. 52. Л. 24; Д. 58. Л. 22 об.

72 РГАДА. Ф. 210. ОП. 1. Д. 11. Л. 39.

73 Это проясняется из «сказки» Я.Г. Тургенева, поданной на сенатском смотрм 1722 г. См.: РГАДА. Ф. 286. Оп. 1. Д. 9. Л. 213. 
спешили «к Рожеству Христову в свещеноссцы выбрать возрастных и толстых, и плешивых» славельщиков ${ }^{74}$. Второе повышение за три года получил родственник Петра Ивановича, упомянутый выше Петр Корчага Бутурлин, став окольничим. Тот же чин из компании «соборян» получил кн. Никита Михайлович Жировой-Засекин, бывший комнатным стольником. Его отец прославился на «всепьянейшем» поприще прозванием «митрополита Мисаила». Княжеский сын превзошел отца, проявив себя на разных службах. В 1706 г. он назначался в ход за иконами, с 1719 г. был воеводой Костромской провинции ${ }^{75}$. О кн. М.Ф. Шаховском, замыкавшем четверку пожалованных в окольничие известно немного, он также как кн. Жировой-Засекин безвыездно жил в новой столице до 1719 г. и едва дождался разрешения Сената выехать для «деревенских своих нужд» на 5 месяцев ${ }^{76}$.

Вновь для желающих добиться «боярской чести» царь преподал очередной урок перед грядущей чиновной реформой. Боярство «было сказано» кн. Ивану Алексеевичу Голицыну. Царь отправил 14 октября 1715 г. сенатору кн. М.В. Долгорукову указ, наполненный едким сарказмом: «посылаю к Вам Екима Волкова, с которым поезжай х князь Ивану Голицыну мужу светейшей княини [Анастасии Петровны ${ }^{77}$. - A. 3.], и вели ему Волкову сказать ему за службу жены его боярство, а ты стой у сказки, да за его тульскую службу червонной золотой, которой бы носил всегда на выи ${ }^{78}$ своей». Более поучительной атмосферы «награждения» было сложно придумать. Указ царя зачитал не сенатор и не дьяк, как водилось прежде, а «карла» Еким Волков по прозвищу Комар. Да и боярством жаловали за придворную службу жены. Новоиспеченный боярин, видимо, стеснялся пользоваться такой «честью» ${ }^{79}$. По крайней мере, в 1722 г. он признался, что в свои 55 лет «в службе вашего императорского величества нигде не бывал» В то время в подобном контексте под «службами» понимались «походы», то есть военная служба. Князь упорно называл себя комнатным стольником, а сенаторы, напротив, в текущих приговорах именовали беднягу боярином, следуя царской воле ${ }^{80}$, напоминали боярским чином пример «достойных заслуг».

Казусы шутовских прозваний перемешивались и вне думских награждений. В 1716 г. думный дворянин и печатник Зотов на старости лет должен был привыкнуть к званию «тайного советника и Ближней канцелярии генерал президента, графа Магнуса Наклевании». Шутовской титул Петр I присвоил ему за «умение» «клевать носом», то есть спать в разгар веселья «соборян» ${ }^{81}$ и прилип-

\footnotetext{
74 РГАДА. Ф. 248. ОП. 12. Д. 649. Л. 676.

75 РГАДА. Ф. 199. Ед. хр. 130. Ч. 16. Д. 6. Л. 5; Ф. 350. Оп. 3. Д. 1. Л. 98.

76 РГАДА. Ф. 248. ОП. 12. Д. 648. Л. 344-346.

77 Княгиня А.П. Голицына, урожденная Прозоровская состояла приближенной «шутихой» царицы Екатерины, участвовала в увеселениях «соборян» в роли «князь-игуменьи».

78 Выя - шея; РГАДА. Ф. 9. Оп. 1. Д. 9. Л. 49-49 об.

79 РГАДА. Ф. 286. Оп. 1. Д. 5. Л. 2; Ф. 350. Оп. 3. Д. 1. Л. 204 об. («Список царедворцев на житье в Петербург» фиксирует состав на 1718 г.); РГАДА. Ф. 286. Оп. 1 Д. 7. Л. 24.

80 В июне 1722 г. «Сенат приказал ис царедворцов Василью Черторыльскому быть при боярине» кн. И. А. Голицыне. См.: РГАДА. Ф. 248. Д. 95. Л. 192-194.

81 Русский биографический словарь. Т. 7: Жабокритский-Зяловский. Изд. под наблюдением
} 
чивый «титул» вновь повторялся в официальных сенатских бумагах ${ }^{82}$. Сенаторам было ничуть не проще, чем нашему современнику провести границу между шутовским и реальным чином.

Среди получивших думные чины после Полтавской победы 1709 г. были люди различного статуса: влиятельные сановники (В.С. Ершов, П.М. Апраксин), деятельные служилые (А.А. Юшков, С.Я.Тургенев), организаторы «соборян» (кн. Ю.Ф. Шаховской, П.И. Бутурлин), для которых заветный чин был способом повысить статус как личный, так и родовой. Придворные шуты, задействованные за редким исключением на различных службах, назначались царем в думные люди в назидание мечтателям о «чести боярской» после каждого случая пожалования служилых людей за нешутовскую службу. Действительная природа и статус пожалования обнаруживается в стилистике царских указов и в контексте карьеры служилого человека. Как ни странно, но в выборе даты и чина награждения, стилистике указов, соблюдены старинные каноны чинопроизводства, поскольку механизм его не был разрушен. Следуя логике вручения думных званий только «дуракам», царю вряд ли стоило скрупулезно учитывать чиновную традицию. Лишь несколько царских подданных, прежде служивших по «московскому списку», добились думных чинов на закате их существования за несомненные служебные доблести. Петр I как дальновидный правитель использовал думные и московские чины, чтобы поддерживать традиционными отличиями служебные заслуги родовитых отпрысков.

Последнее пожалование чином боярина известно в историографии по позднейшей записи в боярской книге 1691/92 г. Екатерина I таким образом наградила стольника С.П. Нелединского-Мелецкого 15 сентября 1725 г. за длительную службу ${ }^{83}$. Этот казус объясним отношением подданного к древним атрибутам чести и лояльностью императрицы к старому чинопроизводству.

С момента единодержавия в 1696 г. прерогатива высших награждений принадлежала единолично Петру I, который после смерти Ивана V включил его комнатных стольников (спальников) в свою «комнату». Вероятнее всего, в память о брате-соправителе Петр І отказался от пожалований в комнатные стольники, поскольку все прежние пожалования «в комнаты» объявлялись царями совместно. Таким образом, последним ${ }^{84}$ в истории получения чина комнатного стольника 14 октября 1695 г. оказался 11-летний Василий Михайлович Ртищев, ставший к началу 1720-х гг. майором Кроншлотского драгунского полка ${ }^{85}$.

председателя Императорского Русского Исторического Общества А. А. Половцова. Под ред. Е. С. Шумигорского и М. Г. Курдюмова. Санкт-Петербург: тип. Гл. упр. уделов, 1897, с. 479.

82 РГАДА. Ф. 248. ОП. 12. Д. 641. Л. 39.

83 РГАДА. Ф. 210. ОП. 1. Д. 11. Л. 31.

84 Остается необъяснимым статус пожалования кн. Ю.Ф. Шаховского. Он попадает в боярский список 1696/97 г. впервые как комнатный стольник, и одновременно числится в перечне стольников вплоть до 1710 г. включительно. Но какой-либо указ или запись о его пожаловании в спальники отсутствуют в боярском списке и разрядах. См.: РГАДА. Ф. 210. Оп. 2. Д. 41. Л. 15 об., 76 об.; Д. 42. Л. 14, 69; Д. 43. Л. 14, 69.

85 РГАДА. Ф. 286. Оп. 1. Д. 7. Л. 2 об. 
Трансформация Боярской думы в практику работы совещаний различных составов, один из которых известен как «консилии министров», а затем учреждение Сената предопределили судьбу думного чинопроизводства. Думные чины сохранились в качестве статусных вознаграждений наиболее отличившихся сподвижников. Среди 9 пожалованных в думные 1695-1701 гг. были выходцы из служилой среды (6 человек), в меньшинстве оказались представители княжеско-боярских фамилий (2 человека). По-прежнему среди награжденных не было представителей недворянских семей, а в думные дьяки был пожалован один дьяк. Основным фактором пожалования впервые за весь XVII в. становится не родство и свойство, а личная служба как для родовитых, так и для служилых отпрысков. Неприкосновенными остаются атрибуты чиновной иерархии, соблюдается порядок записи чиновного награждения ${ }^{86}$, установленные задолго до конца XVII в.

Свои особенности имело возведение в традиционные нижестоящие чины: жильцов, дворян московских, стряпчих и стольников. По надежным данным боярских списков в последний год XVII в. состоялось несколько массовых переводов («записей») из немосковских чинов и несколько персональных пожалований чинов московских. Незадолго до «Свейского похода» 169 царицыных стольников, среди которых упомянут известный в будущем В.Н. Татищев ${ }^{87}$, перевели в царские стольники ${ }^{88}$, в московские дворяне - 100 дворцовых служащих: ключников, чарочников и дворцовых стряпчих ${ }^{89}$. Персональные пожалования получали служилые люди различного статуса и происхождения.

Стольниками из жильцов стали 14 декабря 1699 г. братья Иван Средний и Иван Большой Ильичи Дмитриевы-Мамоновы, последний их которых сражался с начала Северной войны гвардейским офицером и в 1720-е гг. стал морганатическим супругом царевны Прасковьи Ивановны. В московских чинах могли оказаться и наемные иностранцы, что практиковалось и в XVII в. Так, кн. Андрей Васильевич Свирский из литовского княжеского рода был записан 30 ноября 1699 г. в перечень стольников, «служилых с корму», то есть получавших особое жалование. Персонально пожаловали в стольники царя пятерых царицыных стольников, среди которых был 22-летний двоюродный брат царицы Марфы Матвеевны Петр Иванович Ловчиков ${ }^{90}$.

\footnotetext{
86 Думные дворяне не могли получить чин выше окольничего, представители титулованной знати в чине стольника жаловались в окольничие, нетитулованные служилые - не выше думного дворянина.

87 А.В. Захаров. Открывая новые страницы о юности В.Н. Татищева (по документам Разрядного приказа). [В:] Петровское время в лииах. Труды Государственного Эрмитажа. СанктПетербург: Издательство Государственного Эрмитажа, 2008, с. 122-127.

8819 августа 1700 г. 169 человек было «велено написать в полковую службу».Запись в чин ради службы, даже более высокой, лишь условно можно считать пожалованием. РГАДА. Ф. 210. Оп. 2. Д. 43. Л. 473-477 об.

8927 мая 1700 г. 100 «дворовых людей, которые от двора отставлены и присланы для службы в Разряд..., а в Разряде написаны они по московскому списку» то есть в дворяне московские. Там же. Д. 43. Л. 631-633 об.

90 В 1700 г. царскими стольниками стали стольники царицы Прасковьи Федоровны кн.
} 
Регулярные пожалования в стряпчие прекратились летом 1695 г. Единственное иключение царь сделал для Ульяна Акимовича Синявина, как одного из деятельных сотрудников, пожаловали в стряпчие 7 января 1699 г. Спустя полгода в день царских именин Синявин был возведен в стольники. В новом столетии петровский любимец прошел службу от обер-комиссара до генерал-майора. Он был хорошо знаком царю до Великого посольства, во время которого состоял в свите «второго посла» Ф.А.Головина. Вероятнее всего, за эту успешную миссию Синявин и был награжден московскими чинами, которых не достиг его отец за 43-летнюю службу ${ }^{91}$.

Семь последних пожалований в московские дворяне представляют особый интерес, поскольку точно датированы и позволяют уточнить мотивы и статусные роли награждаемых. В московских дворянах в 1700 г. оказался иностранец В.И. Сердаров «из турчан» и четверо городовых дворян ${ }^{92} .1$ декабря 1701 г. был пожалован родной брат местоблюстителя патриаршего престола Федор Иванович Яворский, находившийся «у резанского митрополита в домовых» ${ }^{93}$. Сын стряпчего с ключом Л.Б. Плохова «недоросль» Иван Леонтьевич 28 июня 1707 г. был «за увечьем, что горбат написан по московскому списку». В приписке упоминается любопытное основание: «помета на смотренных тетрадях у записки недорослей» ${ }^{94}$. Достоверно известно, что Петр I лично участвовал в смотрах «царедворцев» и «отмечал в росписи своею рукою» ${ }^{95}$. В последних актах пожалований очевидны ходатайства, поданные царю от влиятельных лиц в сочетании с заслугами представленных к награждению. По письму сенаторов кн. Я.Ф. Долгорукова и графа И.А. Мусина-Пушкина в июле 1713 г. «царское величество указал по именному своему в. г. указу изволил написать во дворяне» 35 -летнего Никона Ивановича Волкова ${ }^{96}$ - видного «купчину», служившего при комнате

И.П. Мещерский (22 января), кн. И.М. Елецкий (26 января), И.А. Лихарев (без указания даты), ранее состоявший в ее свите Ловчиков (28 января), дослужившийся до подполковников, как и М.С. Аничков (3 февраля), бывший стольником царицы Евдокии Федоровны до 1692 г. В 1702 г. последним в список стольников был помещен стряпчий С.М. Дуров, служивший в 1690-е гг .в «летних походах» и под Белгородом, но записи о его возведении в стольники сделано не было. Кроме того, в список стольников «полковой службы» 1700 г. были записаны стряпчие А.Д. Клишков, И.С. Назарьев и 36-летний Л.А. Синявин - все без указания даты и заметок о пожаловании, лишь с отметкой «в стольниках». Там же. Д. 35. Л. 222 об.; Д. 43. Л. 485, 472-472 об., 488 об., 539, 548 об., 569 об., ; Д. 46. Л. 92. Список военным чинам первой половины 18-го столетия. [В:] Сенатский архив. Т. 7. Санкт-Петербург: Типография Правительствующего сената, 1895, с. 687.

91 РГАДА. Ф. 210. оп. 2. Д. 36. Л. 220 об. - 221 об., 236 об.; Д. 43. Л. 121, 220.

92 В 1700 г. были пожалованы Сердаров «по московскому списку за крещение в православную христианскую веру» (28 января), торопчанин кн. И.В. Шаховской и выборный дворянин кн. П.Б. Шаховской (2 марта); 10 марта 1701 г. - «из смольнян» Г.И. Дернов; в 1709 г. ярославец И.И. Тихменев. РГАДА. Д. 43. Л. 658, 641 об.; Д. 45. Л. 293; Д. 56. Л. 182.

93 РГАДА. Ф. 210. Оп. 2. Д. 45. Л. 289.

94 Там же. Д. 53. Л. 121.

95 Желябужский И.А. Указ соч. С. 286.

96 РГАДА. Ф. 286. Оп. 1. Д. 5. Л. 142 
царевны Наталии Алексеевны с 1704 г. ${ }^{97}$ Без сомнений, самые последние награждения московскими чинами сделаны по прямым распоряжениям царя.

Если в нескольких вышеприведенных случаях заметны могущественные покровители (митрополит, придворные, царевна), то мотивы пожалований городовых дворян пока остаются неизвестными.

В течение всей Северной войны регулярные пожалования производились в приказные дьяки ${ }^{98}$, бывшими предпоследними в перечне московского списка, но наиболее практичными в административной сфере. С 1700 до конца 1710 г. дьячество получили 89 подьячих.

В 1702 г. в московском списке вводятся, как и в думном перечне, новые звания и должности. Выше дьяков появляется особая строка «генеральный писарь и секретарь» у дьяка Любима Сергеевича Судейкина - первого в России обладателя секретарской должности по названию и по сути возложенных дел. С 1710 г. в устоявшемся русле чинопроизводства начинается волна новаций. Она отражается и в структуре традиционных чинов. Появляются неизвестные ранее звания и должности: у стольника кн. М.П. Гагарина «генеральной презыдент и московскоий комендант и сибирских правинцей судия», у А.А. Курбатова «оберинспектор ратушского правления». И, наконец, новейшая должность сенатора заняла первый перечень в боярском списке, а ее обладатели автоматически были исключены из чина бояр.

Массовые записи и пожалования состоялись в низший московский чин жильцов. В 1700 г. не менее 400 человек были пожалованы «в житье» и в том числе 130 человек переведены в жилецкий список по указу 28 августа 1700 г. из дворцовых подключников ${ }^{99}$. В течение 1701 г. в жильцы персонально было пожаловано 107 человек, в 1702 г. - 117, в 1703 г. - 80 человек $^{100}$. Единичные записи в жильцы по полкам жилецкого списка проводились и в 1704 г. ${ }^{101}$ Основанием многочисленных пожалований «новиков» в жильцы стала служба их отцов, отставленных из «полковых перечней» по старости или болезням. Поэтому среди «новиков» типичны примеры назначения поместных окладов и отсрочек от службы на несколько лет совсем юным жильцам.

Стоит подчеркнуть, что в чинопроизводстве за службу отцов по сути и проявлялся традиционный характер московских чинов или так называемый генетический фактор традиционной системы управления. Анализ персональных и массовых назначений позволяет уточнить представления о первых чиновных

97 Там же. Д. 7. Л. 1163.

98 С марта 1711 г. чинопроизводством в дьяки занимался Сенат. Только в трех случаях за 1711-1725 гг. в дьячество пожаловали по именным указам. См.: Д.О. Серов. Последние дьяки: из истории реформирования системь гражданских чинов России в первой четверти XVIII в. «Уральский исторический вестник» 2011, № 3, с. 64-72.

99 В жилецком списке 1704 г. из записанных в жильцы в 1700 г. отмечено 414 человек и в том числе 63 человека из бывших 130 подключников. РГАДА. Ф. 210. оп. 3. Д. 69. Л. 77-92 об.; Д. 58. Л. 208-212.

100 Там же. Д. 60. Л. 193-200 об.; Д. 70. Л. 277-290 об., 324-329 об.

101 В жильцы, которым с «704-го году велено служить в Севском полку» были записаны Е.Н. Ширков, Е.Ю. и Е.Ю Шеншины. См.: РГАДА. Ф. 210. оп. 3. Д. 69. Л. 108. 
петровских новациях, предпринятых с последних лет XVII в. Также неоднозначна и практика пожалований в традиционные чины в годы Северной войны. Указ об отмене старомосковских чинов не имел и малейших шансов состояться при понимании монархом отношения служилой среды к привычным отличиям. Думные и московские чины были заметной вехой жизни человека и надолго оставались в памяти награжденного и его рода. Весомый авторитет этих чинов долгое время сохранялся в среде придворной знати, дьячества и рядовых служилых людей, выходцы из которых испытывали чувство значимости в своих прежних отличиях за службу.

На исходе XVII столетия родовитого происхождения для повышения в боярство оказывалось совершенно недостаточно. И, напротив, повышение думным чином как наградой за службу приобретает характер правила. После Полтавской победы, Петр I, не имея значительного арсенала в выборе чиновных почестей, вернулся к спорадическим пожалованиям престижных чинов, проявив удивительную деликатность к поклонникам «боярской чести». Но, отмечая одиозных придворных, царь изобретательно демонстрировал бесплодность стремлений к чинам Московского царства. Необъятное пространство государевой службы постепенно поглощало условные границы московских чинов, поэтому появились примеры нескольких «шутов», допущенных до чиновных вершин и «соборян», выполнявших нешутовскую административную работу.

При детальном рассмотрении практики последних пожалований думных и московских чинов выясняется, что дихотомия «старое-новое» удобна для восприятия административных новшеств как петровскими, так и нашими современниками. Противопоставление различных практик в чиновной сфере оказалось действенным инструментом пропаганды реформаторского начала. В то же время контраст «старого-нового» затрудняет объяснение «рецидивов» существовавших образцов, инертности настроений поклонников привычных почестей и факта сосуществования нескольких иерархических моделей. Причина сохранения элементов московского чинопроизводства в первой четверти XVIII в. кроется, во-первых, в потребности Петра I отметить легитимным способом службу своих ближайших сотрудников и придворных, и, во-вторых, в привычности традиционных начал для самого царя-реформатора. Система чинопроизводства Табели о рангах в действительности не отменяла прежних званий, не задумывалась для умаления московских почестей и принижения заслуг их обладателей. Императивному тону запретов в чиновной сфере была фактически выбрана альтернатива длительных и постепенных политических мероприятий.

\section{Список использованных источников}

РГАДА = Российский государственный архив древних актов Ф. 9, 154, 199, 210, 248, 286.

Двориовые разряды. Т. 3-4. Санкт-Петербург: Типография II Отделения Собственной Его Императорского Величества Канцелярии, 1852-1855.

Досифей. Летописеи, Соловецкий на четыре столетия, от основания Соловец,кого монастыря до настоящего времени, то есть с 1429 по 1833 год. 3-е изд. Москва: В Унив. тип., 1833. 
Древняя Российская вивлиофика. Изд. Н.И. Новиковым. Ч. 9. Москва: Типография компании типографической, 1789.

ПБ = Письма и бумаги императора Петра Великого. Т. 1. Санкт-Петербург, 1887.

Полное собрание русских летописей. Т. 33: Холмогорский и Двинской летописцы. Ленинград: Наука, 1977.

Русская историческая библиотека, издаваемая Археографической комиссией. Т. 21. СанктПетербург: Печатня В.И. Головина, 1907.

Русский архив. 1865. Изд. 2-е. Москва 1866.

Список военным чинам первой половины 18-го столетия. [В:] Сенатский архив. Т. 7. СанктПетербург: Типография Правительствующего сената, 1895.

Холмогоровы В. и Г. Исторические материалы о иерквах и селах XVI-XVIII вв. Вып. 11: Верейская, Дмитровская и Трочиких вотчин десятины (Московского уезда). Москва: Изд. Императ. о-ва Истории и Древностей Российских при Моск. ун-те, 1911.

\section{Литература}

Абрамов А.А. Портрет Петра I времени Великого посольства 1697 г. [В:] Труды Государственного Эрмитажа. Т. 70: Петровское время в лииах: К 400-летию Дома Романовых (1613-2013). Санкт-Петербург: Издательство Государственного Эрмитажа, 2013.

Беспятых Ю.Н. Третье «пришествие» Петра I на Белое море. [В:] Архангельск в XVIII в. Сост. и отв. ред. Ю.Н. Беспятых. Санкт-Петербург: Русско-балтийский информ. центр «БЛИЦ», 1997, с. 31-32.

Богословский М.М. Петр I. Материаль для биографии. Т. 4. Москва: Госполитиздат, 1948, c. $243-258$.

Грунд Г. Доклад о России в 1705-1710 г2. Пер. Ю.Н. Беспятых. Санкт-Петербург: Институт российской истории, 1992.

Желябужский И.А. Записки. [В:] Россия при иаревне Софье и Петре I: записки русских людей. Сост., автор вступит. ст., коммент. и указ. А.П. Богданов. Москва: Современник, 1990.

Захаров А.В. Открывая новые страницы о юности В.Н. Татищева (по документам Разрядного приказа). [В:] Петровское время в лииах. Труды Государственного Эрмитажа. СанктПетербург: Издательство Государственного Эрмитажа, 2008, с. 122-127.

Захаров А.В. Государев двор Петра I: публикация и исследование источников разрядного делопроизводства. Челябинск: Челябинский государственный университет, 2009.

Захаров А.В. «Государев двор» и иаредвориы Петра I: проблемы терминологии и реконструкиии службы. [В:] Правящие элиты и дворянство России во время и после Петровских реформ (1682-1750). Ред. Н.Н. Петрухинцев, Л. Эррен, А.В. Доронин. Москва: Российская политическая энциклопедия, 2012, с. 10-44.

Захаров А.В. Боярин и первый сенатор Иван Алексеевич Мусин-Пушкин на службе и в кругу семьи. [В:] Труды государственного Эрмитажа. Т. 78: Петровское время в лицах. СанктПетербург: Издательство Государственного Эрмитажа, 2015, с. 229-236.

Котошихин Г.К. О России в иарствование Алексея Михайловича. 3-е изд. Санкт-Петербург, 1884.

Куракин Б.И. Гистория о Петре I и ближних к нему людях. «Русская старина» 1890. Т. 68, № 10. Лукичев М.П. Боярские книги XVII века: труды по истории и источниковедению. Москва: Древлехранилище, 2004.

Медушевский А.Н. Утверждение абсолютизма в России: сравнительное историческое исследование. Москва: Текст, 1994. 
Петербург в эпоху Петра I: документ в фондах и коллекииях НИА СПбИИ РАН. Каталог. Сост. Е.А. Андреева, Т.А. Базарова и др. Ч. 1. Санкт-Петербург: Санкт-Петербургский филиал архива РАН, 2003.

Письма и бумаги имп. Петра Великого. Т. 1: 1688-1701. Санкт-Петербург: Гос. тип., 1887.

Платонов С.Ф. Из бытовой истории Петровской эпохи. Любимцы Петра Великого: Медведь, Битка и др. «Известия Академии наук СССР». Серия VI, № 9, с. 655-678.

Походный журнал 1712 г. Санкт-Петербург, 1913.

Руммель В.В., Голубцов В.В. Родословный сборник русских дворянских фамилий. Т. 2. СанктПетербург: Издание А. С. Суворина, 1887.

Русский биограбический словарь. Т. 7: Жабокритский-Зяловский. Изд. под наблюдением председателя Императорского Русского Исторического Общества А. А. Половцова. Под ред. Е. С. Шумигорского и М. Г. Курдюмова. Санкт-Петербург: тип. Гл. упр. уделов, 1897.

Седов П.В. Закат Московского изарства: изарский двор конца XVII века. Москва: Дмитрий Буланин, 2006.

Серов Д.О. Последние дьяки: из истории реформирования системы гражданских чинов России в первой четверти XVIII в. «Уральский исторический вестник» 2011, № 3, с. 64-72.

Серов Д.О. Администрация Петра І. Москва: ОГИ, 2007.

Хоруженко О.И. Дворянские дипломы XVIII века в России. Москва: Наука, 1999.

Юль Ю. Записки датского посланника в России. [В:] Лавры Полтавы. Москва: Фонд Сергея Дубова, 2001.

Hughes L. „A Beard is an Unnecessary Burden”: Peter I's Laws on Shaving and their Roots in Early Russia. [B:] Russian Society and Culture and the Long Eighteenth Century: Essays in Honour of Anthony G. Cross. Ed. R. Bartlett, L. Hughes. Münster: Lit, 2004.

Poe M.T. The Russian Elite in the Seventeenth Century. Vol. 1-2. Helsinki: Academia Scientiarum Fennica, 2004.

Zitser E.A. The Transfigured Kingdom. Sacred Parody and Charismatic Authority at the Court of Peter the Great. Ithaca and London: Cornell University Press, 2004, c. 96-100. 